\title{
Cholesterol Enrichment Increases Basal and Agonist-stimulated Calcium Influx in Rat Vascular Smooth Muscle Cells
}

Russell A. Bialecki, ${ }^{*}$ Thomas N. Tulenko, ${ }^{\star}$ and Wilson S. Colucci ${ }^{\star}$

*Cardiovascular Division, Departments of Medicine, Brigham and Women's Hospital and Harvard Medical School, Boston, Massachusetts 02115; and ${ }^{\ddagger}$ Department of Physiology and Biochemistry,

The Medical College of Pennsylvania, Philadelphia, Pennsylvania 19129

\section{Abstract}

The effect of cholesterol enrichment on vascular smooth muscle cell (VSMC) calcium homeostasis was studied by evaluating calcium uptake, efflux, and intracellular content in cultured VSMC derived from the rat pulmonary artery. Incubation of VSMC with liposomes consisting of free cholesterol (FC) and phospholipid (2:1 molar ratio, $1 \mathrm{mg} \mathrm{FC} / \mathrm{ml}$ medium) for $24 \mathrm{~h}$ resulted in a $69 \pm 19 \%$ increase $(P<0.01 ; n=10)$ in FC which was associated with a $73 \pm 11 \%$ increase $(P<0.005 ; n=10)$ in intracellular calcium content as assessed by isotopic equilibrium with ${ }^{45} \mathrm{Ca}^{2+}$ and a $65 \pm 11 \%$ increase $(P<0.024 ; n=3)$ as assessed by atomic absorption spectroscopy. Cholesterol enrichment caused a marked increase in the unidirectional calcium uptake rate from $0.026 \pm 0.03$ to $0.158 \pm 0.022 \mathrm{nmol}$ calcium/s per mg protein $(P<0.01 ; n=3)$, but had no effect on calcium efflux. Nifedipine $(1 \mu \mathrm{M})$ reduced $(P<0.05 ; n=6)$ the effect of cholesterol enrichment on unidirectional calcium uptake by $78 \pm 16 \%$; and verapamil $(10 \mu M)$, diltiazem $(1 \mu M)$, and nifedipine $(1 \mu \mathrm{M})$ each significantly inhibited the effect of cholesterol enrichment on intracellular calcium accumulation. Exposure of cholesterol-enriched VSMC to cholesterol-poor liposomes for $24 \mathrm{~h}$ returned both FC and calcium contents to control levels. Serum- and serotonin-stimulated calcium uptakes were potentiated 3.7- and 1.7-fold, respectively, in cholesterol-enriched VSMC, whereas endothelin, vasopressin, and thrombin-stimulated calcium uptakes were not affected. We conclude that VSMC FC content plays a role in regulating cellular calcium homeostasis, both under basal conditions and in response to selected agonists. (J. Clin. Invest. 1991. 88:18941900.) Key words: calcium efflux • liposomes • verapamil • nifedipine $\cdot$ diltiazem

\section{Introduction}

Unesterified (i.e., free) cholesterol is a major constitutent of the plasma membrane of mammalian cells, including the vascular smooth muscle cell (VSMC), ${ }^{1}$ and plays an important role in

Address correspondence to Wilson S. Colucci, M.D., Cardiovascular Division, Brigham and Women's Hospital, 75 Francis Street, Boston, MA 02115.

Received for publication 27 February 1991 and in revised form 27 June 1991

1. Abbreviations used in this paper: FC, free cholesterol; PL, phospholipid; PSS, physiological salt solution; VSMC, vascular smooth muscle cells.

\section{J. Clin. Invest.}

(c) The American Society for Clinical Investigation, Inc.

0021-9738/91/12/1894/07 \$2.00

Volume 88, December 1991, 1894-1900 determining both the physical state of the cell membrane $(1,2)$ and the activities of integral membrane proteins (3-5). In red blood cells, cholesterol enrichment caused by exposing cells to cholesterol-rich liposomes results in a marked increase in calcium influx, the magnitude of which correlates with membrane cholesterol content (6). Thus, one important cellular process that appears sensitive to alterations in plasma membrane cholesterol content is the influx of extracellular calcium.

The effect of an alteration in VSMC plasma membrane cholesterol content on the influx and intracellular accumulation of calcium is not known. However, Strickberger et al. (7) have provided evidence that both calcium uptake and intracellular calcium content are increased in the aorta of the cholesterol-fed rabbit, and have suggested that this change in calcium transport might reflect an effect of cholesterol on the VSMC plasma membrane. This suggestion is also consistent with the observation that perfusion of rabbit carotid artery with cholesterol-rich liposomes is associated with an increase in vascular calcium uptake (8).

To test the hypothesis that an increase in cellular free cholesterol results in increases in basal transplasmalemmal calcium influx and intracellular calcium accumulation in VSMC, we enriched the plasma membrane cholesterol content of cultured VSMC by maintaining the cells in culture medium supplemented with cholesterol-rich liposomes for $24 \mathrm{~h}$. Calcium influx, efflux, and intracellular accumulation were measured by standard methods using ${ }^{45} \mathrm{Ca}^{2+}$ as a tracer. Since there is evidence that the vasoconstrictor and growth-stimulating effects of some agonists and growth factors may be increased by cholesterol enrichment of VSMC (9-13), we also tested the hypothesis that cholesterol enrichment of VSMC increases agoniststimulated calcium influx by evaluating the effect of VSMC cholesterol enrichment on calcium uptake stimulated by serotonin, thrombin, endothelin, vasopressin, and serum.

\section{Methods}

Cell culture. A clonal cell line derived from rat pulmonary artery smooth muscle, as originally established and characterized by Rothman et al. $(14,15)$, was used for these studies. These cells express smooth muscle $\alpha$-actin (14) and mRNA for smooth muscle $\alpha$-actin (15). Cells were seeded in 35-mm plastic culture dishes (Falcon Labware, Becton, Dickinson \& Co., Oxnard, CA) at a density of 10,000$12,000 \mathrm{cells} / \mathrm{cm}^{2}$, and grown in M199 medium (Sigma Chemical Co., St. Louis, MO) containing antibiotics and $5 \%$ fetal calf serum (Gibco Laboratories, Grand Island, NY) in a humidified atmosphere under 5\% $\mathrm{CO}_{2} / 95 \%$ room air $\left(37^{\circ} \mathrm{C}\right)$. Cells reached confluence in $\sim 3-4 \mathrm{~d}$ and were used for experimentation between 3 and $5 \mathrm{~d}$ after passage. All experiments were performed using confluent cell monolayers from passages 28-40. All monolayers were incubated in serum-free medium for 18-24 $\mathrm{h}$ before experimentation to remove the influence of growth factors contained in fetal calf serum. 
Cholesterol enrichment of VSMC. Multilamellar liposomes were prepared from cholesterol and egg phosphatidylcholine using the procedures previously described (8). Chromatographically pure unesterified cholesterol $(96 \mathrm{mg})$ and egg phosphatidylcholine $(48 \mathrm{mg})$ were added to $12 \mathrm{ml}$ of isotonic M199 medium and sonicated for $20 \mathrm{~min}$ with a sonifier (Branson Instruments, Danbury, CT). The mixture was then centrifuged $(42,000 \mathrm{~g}, 30 \mathrm{~min})$ to sediment the undispersed lipid. This procedure yielded cholesterol-rich liposomes with a free cholesterol/phospholipid (FC/PL) molar ratio of $\sim 2: 1$ as determined by FC fluorometry and phospholipid phosphorus colorimetry (see Analytical Determinations). Pure phospholipid liposomes were also prepared using only egg phosphatidylcholine $(48 \mathrm{mg})$ to produce cholesterol-free liposomes with FC/PL molar ratios of 0:1. Liposomes were filter sterilized $(0.45 \mu \mathrm{m}$; Millipore Corp., Bedford, MA) and added to sterile M199 incubation medium at the final concentrations indicated. The FC/PL mass ratios of liposomes were confirmed before experimentation. For cholesterol enrichment, confluent VSMC monolayers were incubated for $24 \mathrm{~h}\left(37^{\circ} \mathrm{C}, 5 \% \mathrm{CO}_{2} / 95 \%\right.$ room air, humidified atmosphere) in medium M199 containing: (a) liposomes in a final concentration of $0.3-2.0 \mathrm{mg}$ of $\mathrm{FC} / \mathrm{ml}$ of incubation medium; $(b) 0.2 \% \mathrm{wt} / \mathrm{vol}$ BSA (fraction V BSA, fatty acid free); (c) $1 \% \mathrm{vol} / \mathrm{vol}$ FCS; and $(d) 1.0$ $\mu \mathrm{g} / \mathrm{ml}$ Sandoz Compound 58-035 to inhibit acyl CoA: cholesterol acyltransferase activity (16). Based on preliminary studies of FC and cholesterol ester contents, a cholesterol-rich liposome concentration of $1 \mathrm{mg}$ $\mathrm{FC} / \mathrm{ml}$ was used for all studies, unless otherwise indicated. In several experiments, cholesterol-enriched and control VSMC were maintained for an additional $24 \mathrm{~h}$ in media containing cholesterol-free liposomes (0:1 FC/PL; $0.5 \mathrm{mg} \mathrm{PL} / \mathrm{ml}$, final concentration).

Calcium uptake. Calcium uptake was measured as previously described (17). The physiological salt solution (PSS) used in these studies consisted of $145 \mathrm{mM} \mathrm{NaCl}, 5 \mathrm{mM} \mathrm{KCl}, 1 \mathrm{mM} \mathrm{MgCl}_{2}, 1 \mathrm{mM} \mathrm{CaCl}_{2}, 1$ $\mathrm{mg} / \mathrm{ml} \mathrm{BSA}, 10 \mathrm{mM}$ glucose, and $5 \mathrm{mM}$ Hepes at $\mathrm{pH} 7.40$. Briefly, the uptake period was initiated by the addition of $1 \mathrm{ml}$ PSS containing 1 $\mu \mathrm{Ci} / \mathrm{ml}$ of ${ }^{45} \mathrm{Ca}^{2+}$ and the agent(s) under study. Uptake was terminated at various time intervals by rapidly washing each plate five times with 1 $\mathrm{ml}$ of ice-cold modified PSS that contained $10 \mathrm{mM} \mathrm{LaCl}_{3}$ and no $\mathrm{CaCl}_{2}$. Lanthanum displaces ${ }^{45} \mathrm{Ca}^{2+}$ from extracellular binding sites and reduces calcium movement across the plasma membrane, thus allowing the assessment of intracellular calcium $(18,19)$. The monolayers were incubated for $10 \mathrm{~min}$ at $4^{\circ} \mathrm{C}$ in the final wash aliquot. Subsequently, the wash solution was aspirated and the cells were dried at room temperature for $10 \mathrm{~min}$. The cell monolayers were then dissolved in $0.1 \mathrm{~N} \mathrm{HNO}_{3}\left(20 \mathrm{~min}, 4^{\circ} \mathrm{C}\right)$. The acid soluble cellular material was transferred to scintillation vials and the radioactivity counted using standard scintillation techniques. Calcium uptake (expressed in nmol calcium/mg protein) was determined as the counts (cpm) derived from the acid soluble material divided by the specific activity of the ${ }^{45} \mathrm{Ca}^{2+}$ containing uptake media (cpm/mol calcium).

Calcium efflux. Calcium efflux was measured as previously reported (17). Briefly, cell monolayers were equilibrated with ${ }^{45} \mathrm{Ca}^{2+}(1$ $\mu \mathrm{Ci} / \mathrm{ml}$ ) for $24 \mathrm{~h}$ in $\mathrm{M} 199$ medium. After equilibration, the cells were washed rapidly three times with $1 \mathrm{ml}$ of PSS at $37^{\circ} \mathrm{C}$. Efflux of ${ }^{45} \mathrm{Ca}^{2+}$ was initiated by the addition of $1 \mathrm{ml}$ of PSS, and the assay was terminated after 6 min using the procedures described for the calcium uptake assay.

Intracellular calcium content by isotopic equilibrium. Intracellular calcium content was measured as previously reported (17). Confluent cell monolayers were brought to isotopic equilibrium with ${ }^{45} \mathrm{Ca}^{2+}$ by incubation for $24 \mathrm{~h}\left(37^{\circ} \mathrm{C}, 5 \% \mathrm{CO}_{2} / 95 \%\right.$ room air, humidified atmosphere) in $1 \mathrm{ml}$ of fresh M199 medium containing $1 \mu \mathrm{Ci} / \mathrm{ml} \mathrm{of}^{45} \mathrm{Ca}^{2+}$ in the presence or absence of liposomes. In some experiments, voltagesensitive calcium channel antagonists were included in the medium. The assay was terminated after $24 \mathrm{~h}$ using the procedures described for calcium uptake.

Intracellular calcium content by atomic absorption spectroscopy. Cellular calcium content was also measured using atomic absorption spectroscopy as previously described $(17,20)$ with minor modifications. Confluent monolayers grown in $150-\mathrm{mm}$ dishes were incubated for $24 \mathrm{~h}$ in the presence or absence of liposomes. The incubation period was terminated by rapidly washing each dish three times with $10 \mathrm{ml}$ of ice-cold modified PSS in which $10 \mathrm{mM} \mathrm{LaCl}_{3}$ and $145 \mathrm{mM}$ choline were substituted for $\mathrm{CaCl}_{2}$ and $\mathrm{NaCl}$, respectively. The cells were then washed two additional times with 15 -ml aliquots of an ice-cold solution consisting of $5 \mathrm{mM}$ Hepes, $300 \mathrm{mM}$ sucrose, and $10 \mathrm{mM} \mathrm{LaCl}_{3}, \mathrm{pH}$ $=7.4$. The washed monolayer was scraped and transferred to a vial using four successive 4-ml aliquots of the modified PSS containing lanthanum and choline. The cell suspension was centrifuged for 10 $\min \left(450 \mathrm{~g}, 4^{\circ} \mathrm{C}\right)$ and the supernatant discarded. The cell pellet was then dissolved in $1 \mathrm{ml}$ of $0.1 \mathrm{~N} \mathrm{HNO}_{3}$ at room temperature overnight. Acid soluble cellular material was prepared for spectroscopic analysis the next day by 20 -min incubation in a boiling water bath, centrifugation to remove the insoluble material $(4 \mathrm{~min}$ at $4,000 \mathrm{~g}$ ) and collection of the supernatant. Atomic absorption spectroscopy was performed using a 0.8-ml sample aliquot in a (model 5000; Perkin Elmer Corp., Norwalk, CT) with absorbance at $422.7 \mathrm{~nm}$. Experimental values were compared to a calcium standard dilution curve freshly prepared in 0.1 $\mathrm{N} \mathrm{HNO}_{3}$.

Analytical determinations. The cholesterol, phospholipid, and protein contents of VSMC were determined from sister plates in parallel with the ${ }^{45} \mathrm{Ca}^{2+}$ flux studies. Monolayers were scraped from culture dishes with a rubber spatula using $5 \mathrm{vol}$ of 2-propanol at $4^{\circ} \mathrm{C}$. The aliquots were pooled and the suspension was sonicated to insure cell disruption. FC and total cholesterol (esterified + free) contents were measured using a fluorescent cholesterol assay according to Gamble et al. (21). Briefly, to assess FC, cholesterol oxidase is added to generate $\mathrm{H}_{2} \mathrm{O}_{2}$, and peroxidase is added to catalyze the reaction of $\mathrm{H}_{2} \mathrm{O}_{2}$ with p-hydroxyphenylacetic acid to generate a stable fluorescent product which is quantitated with a spectrofluorometer (excitation $325 \mathrm{~nm}$, emission $415 \mathrm{~nm}$ ). Cholesterol hydrolase is included for determination of total cholesterol. The phospholipid mass was determined by phospholipid phosphorus colorimetry according to Sokaloff and Rothblatt (22). Briefly, after drying down under nitrogen gas, the liquid residue is digested in $\mathrm{H}_{2} \mathrm{SO}_{4}-60 \% \mathrm{HClO}_{4}(4: 1, \mathrm{vol} / \mathrm{vol})$ at $180^{\circ} \mathrm{C}$ for $2 \mathrm{~h}$. After cooling, color proportional to inorganic phosphorus is developed by adding $0.4 \mathrm{ml} 5 \%$ ammonium molybdate and $0.2 \mathrm{ml} 0.15 \%$ hydrazine sulfate in $2 \mathrm{ml} \mathrm{H}_{2} \mathrm{O}$, and heating at $100^{\circ} \mathrm{C}$ for $20 \mathrm{~min}$. Samples are read in a spectrophotometer at $600 \mathrm{~nm}$. All lipid assays were performed in triplicate. Protein content was determined by scraping cell monolayers into $5 \mathrm{vol}$ of $0.1 \mathrm{~N} \mathrm{NaOH}$. The protein mass was assayed according to the method of Lowry et al. (23).

Analysis of data. Statistical significance was determined by the Student two-tailed $t$ test for paired or unpaired comparisons, as appropriate. $P$ values $<0.05$ were considered significant. All experiments were performed in triplicate. All data are presented as mean \pm SEM.

Reagents. ${ }^{45} \mathrm{Ca}^{2+}\left(19.6 \mathrm{mCi} / \mathrm{mg} \mathrm{Ca}{ }^{2+}\right)$ was obtained from ICN Biomedicals, Inc., Irvine, CA. Free cholesterol, egg phosphatidylcholine, fraction V BSA, verapamil, diltiazem, nifedipine, serotonin, vasopressin, and thrombin were obtained from Sigma Chemical Co. Endothelin was obtained from Calbiochem Corp., La Jolla, CA, and FCS was obtained from Gibco. Sandoz Compound 58-035 was a generous gift from Dr. James Paternitti, Sandoz Pharmaceuticals, Inc. Drugs that required dissolution in either ethanol (e.g., verapamil) or DMSO (e.g., 58-035) were adjusted to a final vehicle concentration of $1: 10,000$ at the drug concentrations indicated, and control cells were incubated with the appropriate vehicle at a final concentration of $1: 10,000$.

\section{Results}

Effect of cholesterol-rich and cholesterol-free liposomes on VSMC lipid content. The FC content of control VSMC averaged 12.6 $\pm 1.8 \mu \mathrm{g} \mathrm{FC} / \mathrm{mg}$ protein. VSMC incubated for $24 \mathrm{~h}$ with cholesterol-rich (2:1 FC/PL) liposomes at final concentrations ranging from 0.0 to $2.0 \mathrm{mg} \mathrm{FC} / \mathrm{ml}$ in the incubation medium demonstrated that the increase in cellular FC content is linearly related $(r=0.98 ; P<0.001)$ to the concentration of 
liposomes in the medium (Fig. 1). Incubation of VSMC with cholesterol-rich liposomes in a concentration of $1 \mathrm{mg} \mathrm{FC} / \mathrm{ml}$ for $24 \mathrm{~h}$ resulted in an average $74 \pm 8 \%$ increase $(P<0.01 ; n=8)$ in FC content compared to control VSMC not incubated with liposomes or incubated with cholesterol-free phospholipid (0:1 FC/PL) liposomes (Table I).

Neither cholesterol ester content (total cholesterol minus free cholesterol) nor phospholipid content was affected by 24-h incubation with cholesterol-rich liposomes in a concentration of $1 \mathrm{mg} \mathrm{FC} / \mathrm{ml}$ medium (Table $\mathrm{I}$ ). The molar ratio of $\mathrm{FC}$ to phospholipid, an index of membrane FC content (2), was significantly increased by incubation with cholesterol-rich liposomes. VSMC exposed to cholesterol-free phospholipid liposomes for $24 \mathrm{~h}$ did not demonstrate changes in cellular FC, cholesterol ester, or phospholipid contents compared with nontreated controls (Table I).

Effect of cholesterol enrichment on VSMC intracellular calcium content. The intracellular calcium content of control cells as measured by isotopic equilibration averaged $7.7 \pm 0.8 \mathrm{nmol}$ calcium $/ \mathrm{mg}$ protein $(n=9)$. There was a strong linear relationship ( $r=0.99, P<0.001)$ between VSMC FC content and intracellular calcium content over a cellular FC range of 5 to 21 $\mu \mathrm{g} / \mathrm{mg}$ protein (Fig. 2). Incubation with cholesterol-rich liposomes in a concentration of $1 \mathrm{mg} \mathrm{FC} / \mathrm{ml}$ for $24 \mathrm{~h}$ increased VSMC FC content by $69 \pm 19 \%(P<0.009 ; n=10)$ and was associated with a $73 \pm 11 \%(P<0.005 ; n=10)$ increase in intracellular calcium content as measured by the isotopic equilibration method. Atomic absorption measurements likewise demonstrated a $65 \pm 11 \%(P<0.024 ; n=3)$ increase in intracellular calcium content after incubation with cholesterol-rich liposomes in a concentration of $1 \mathrm{mg} \mathrm{FC} / \mathrm{ml}$ for $24 \mathrm{~h}$, as compared to control cells not exposed to liposomes ( $14.0 \pm 1.6 \mathrm{vs}$. $9.3 \pm 1.2$ $\mathrm{nmol}$ calcium/mg protein, respectively).

Experiments were performed to determine if the increase in intracellular calcium content of cholesterol-rich cells is reversible upon removal of the excess cholesterol (Fig. 3). For these experiments, VSMC were incubated with medium containing

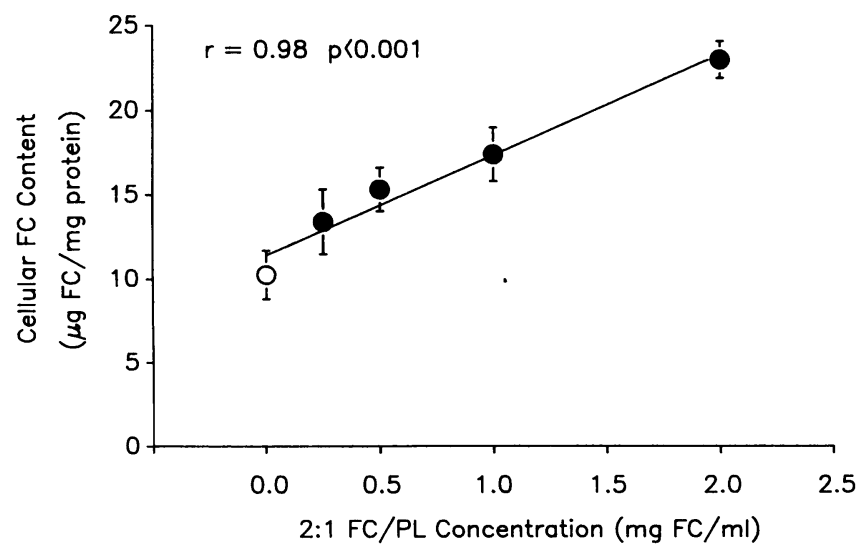

Figure 1. Relationship between cholesterol-rich liposome (2:1 FC/PL) concentration and cellular free (unesterified) cholesterol (FC) content after addition of liposomes to the cell culture medium for $24 \mathrm{~h}$. The concentration of 2:1 FC/PL liposomes is expressed as milligrams of liposomal FC per milliliter of incubation media. Control cells (open circle) incubated without liposomes are shown for comparison. Data represent the mean \pm SEM of triplicate determinations from a representative experiment.
Table I. Cholesterol and Phospholipid Contents of Control VSMC, and VSMC Incubated with Cholesterol-rich Liposomes (2:1 FC/PL) or Cholesterol-free Phospholipid Vesicles $(0: 1 F C / P L)^{*}$

\begin{tabular}{cccc}
\hline & Control & $2: 1 \mathrm{FC} / \mathrm{PL}$ & $0: 1 \mathrm{FC} / \mathrm{PL}$ \\
\hline $\begin{array}{c}\text { Free cholesterol } \\
(\mu \mathrm{g} / \mathrm{mg} \text { protein })\end{array}$ & $12.6 \pm 1.8$ & $21.8 \pm 2.6^{\ddagger}$ & $10.0 \pm 2.1$ \\
$\begin{array}{c}\text { Cholesterol ester } \\
(\mu \mathrm{g} / \mathrm{mg} \text { protein })\end{array}$ & $0.105 \pm 0.013$ & $0.129 \pm 0.015$ & $0.116 \pm 0.017$ \\
$\begin{array}{c}\text { Phospholipid } \\
(\mu \mathrm{g} / \mathrm{mg} \text { protein })\end{array}$ & $242 \pm 17$ & $266 \pm 21$ & $254 \pm 36$ \\
Protein (mg/cm $\left.{ }^{2}\right)$ & $0.019 \pm 0.003$ & $0.018 \pm 0.002$ & $0.020 \pm 0.004$ \\
FC/PL molar ratio & $0.113 \pm 0.018$ & $0.186 \pm 0.028^{\S}$ & $0.081 \pm 0.039$
\end{tabular}

*Data are mean values from eight experiments, each performed in triplicate.

${ }^{\ddagger} P<0.01,2: 1$ vs. control and 0:1 FC/PL.

${ }^{8} P<0.05,2: 1$ vs. control and $0: 1 \mathrm{FC} / \mathrm{PL}$.

no liposomes (control medium), cholesterol-poor liposomes (0:1, FC/PL; $0.5 \mathrm{mg} \mathrm{PL/ml} \mathrm{medium),} \mathrm{or} \mathrm{cholesterol-rich} \mathrm{lipo-}$ somes $(2: 1, \mathrm{FC} / \mathrm{PL} ; 1 \mathrm{mg} \mathrm{FC} / \mathrm{ml}$ medium) for $48 \mathrm{~h}$. After the first $24 \mathrm{~h}$, half of the plates which had been incubated with control or cholesterol-rich medium were changed to cholesterol-poor medium for the second $24 \mathrm{~h}$. Compared to VSMC incubated with control medium for the entire $48 \mathrm{~h}$, cells exposed to cholesterol-poor liposomes for 24 or $48 \mathrm{~h}$ exhibited no change in free cholesterol and calcium content. In VSMC incubated with cholesterol-rich medium for $48 \mathrm{~h}$, free cholesterol and calcium were substantially enriched by $48 \pm 16 \%$ and $74 \pm 17 \%$, respectively, versus control cells, an effect comparable to that seen after 24-h incubation with cholesterol-rich medium in the prior experiments.

In VSMC incubated with cholesterol-rich medium for the first $24 \mathrm{~h}$, followed by cholesterol-poor medium for the second

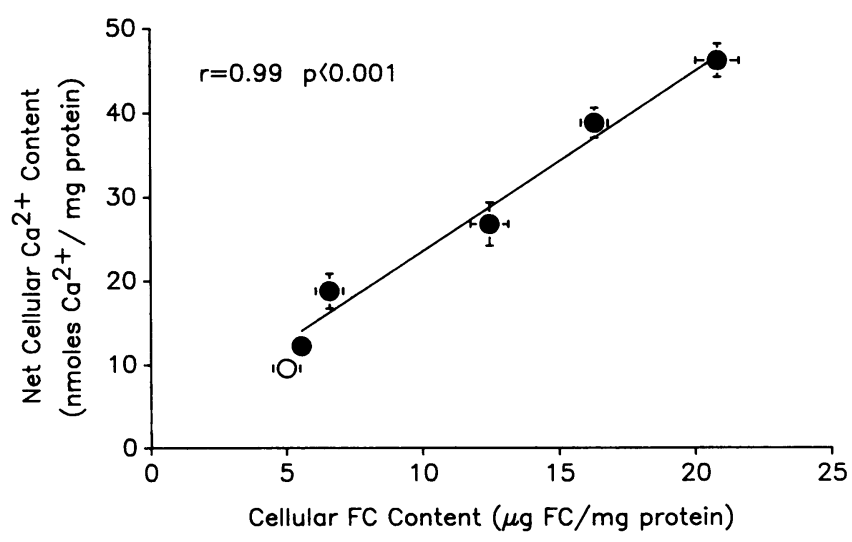

Figure 2. Relationship between free (unesterified) cholesterol (FC) content and calcium content of VSMC incubated for $24 \mathrm{~h}$ with various concentrations of cholesterol-rich liposomes (filled circles). Calcium content was determined by isotopic equilibration with ${ }^{45} \mathrm{Ca}^{2+}$. Control cells (open circle) incubated without liposomes are shown for comparison. Each point represents the mean \pm SEM of triplicate determinations from a representative experiment. 


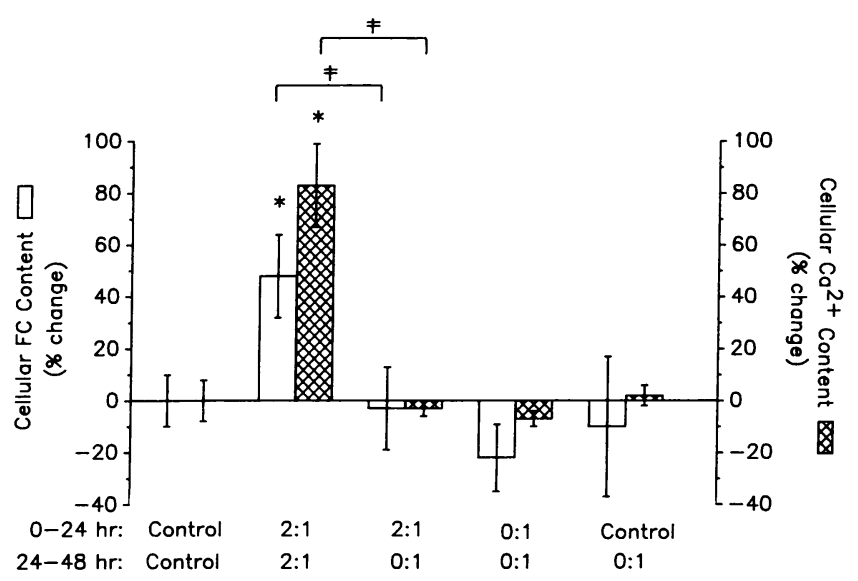

Figure 3. Reversibility of the effect of cholesterol enrichment on VSMC cellular calcium content. VSMC were incubated for $24 \mathrm{~h}$ with medium containing no liposomes (control medium), cholesterol-poor liposomes ( $0: 1, \mathrm{FC} / \mathrm{PL} ; 0.5 \mathrm{mg} \mathrm{FC} / \mathrm{ml}$ medium), or cholesterol-rich liposomes (2:1, FC/PL; $1 \mathrm{mg} / \mathrm{ml}$ medium) for $48 \mathrm{~h}$. After $24 \mathrm{~h}$, half of the cells incubated with control or cholesterol-rich medium, were changed to cholesterol-poor medium for the second $24 \mathrm{~h}$. Results are shown as percent change from cells incubated with control medium for the entire $48 \mathrm{~h}$. Control values for free cholesterol and calcium content were $14.4 \pm 1.8 \mu \mathrm{g} / \mathrm{mg}$ protein and $6.4 \pm 0.8 \mathrm{nmol}$ calcium $/ \mathrm{mg}$ protein, respectively. Data represent the mean \pm SEM of three experiments. ${ }^{*} P<0.002$ compared with cells grown in control media for $48 \mathrm{~h} ;{ }^{\ddagger} P<0.01$ for the indicated comparison.

$24 \mathrm{~h}$, the increases in free cholesterol and calcium were completely reversed so that free cholesterol and calcium were not different from that in cells incubated with control medium for $48 \mathrm{~h}$, or control medium for $48 \mathrm{~h}$ followed by cholesterol-poor medium for $24 \mathrm{~h}$. Cellular phospholipid content was not affected by any of the conditions (data not shown).

Effect of cholesterol enrichment on basal VSMC calcium uptake and efflux. To determine whether the increase in intracellular calcium content is associated with an increase in calcium uptake rate, the early time course of calcium uptake was examined under basal conditions in cholesterol-enriched and control VSMC (Fig. $4 A$ ). Calcium uptake was linear over the first $15 \mathrm{~s}$ in both cholesterol-enriched and control VSMC, reflecting unidirectional uptake (Fig. $4 \mathrm{~B}$ ). The unidirectional calcium uptake rate determined over the first $15 \mathrm{~s}$ was significantly increased in cholesterol-enriched versus control VSMC $(0.16 \pm 0.02$ vs. $0.03 \pm 0.003 \mathrm{nmol}$ calcium/s per $\mathrm{mg}$ protein, respectively; $P<0.001 ; n=3$ ). Net calcium uptake at $8 \mathrm{~min}$ was also markedly augmented in cholesterol-enriched VSMC as compared to controls $(2.9 \pm 0.1$ versus $1.2 \pm 0.1 \mathrm{nmol}$ calcium $/ 8$ min per mg protein, respectively; $P<0.01 ; n=3$ ). The effect of voltage-dependent calcium channel blockade on the cholesterol-mediated increase in calcium uptake was evaluated using nifedipine. Nifedipine ( $1 \mu \mathrm{M} ; 30 \mathrm{~min})$ reduced the effect of cholesterol enrichment on 15 -s calcium uptake by $78 \pm 16 \%$ $(P<0.05 ; n=6)$.

To evaluate the effect of increased cellular cholesterol content on basal calcium efflux, VSMC were equilibrated for $24 \mathrm{~h}$ with ${ }^{45} \mathrm{Ca}^{2+}$ in the presence or absence of cholesterol-rich liposomes. Cholesterol enrichment had no effect on basal calcium efflux over $6 \mathrm{~min}$ (control cells, $0.27 \pm 0.03 \mathrm{nmol} / 6 \mathrm{~min}$; cholesterol-enriched cells, $0.29 \pm 0.04 \mathrm{nmol} / 6 \mathrm{~min} ; n=6 ; P=\mathrm{NS}$ ).

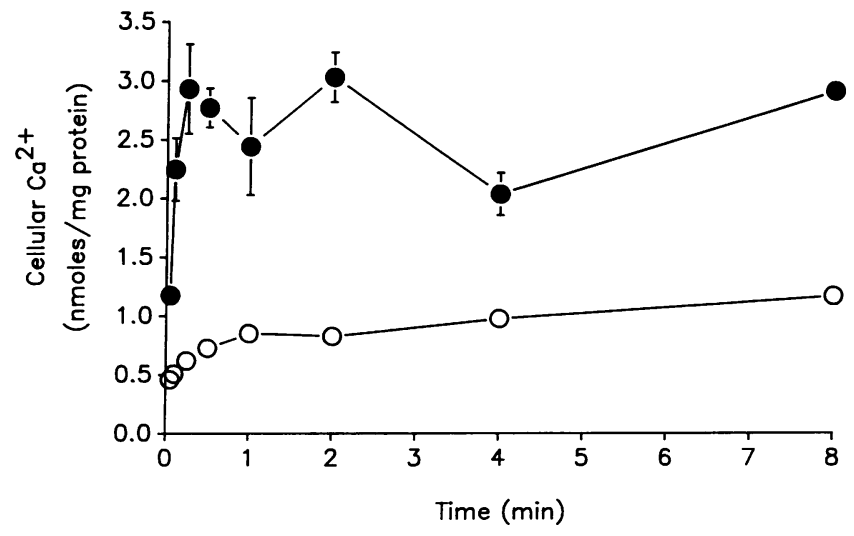

B

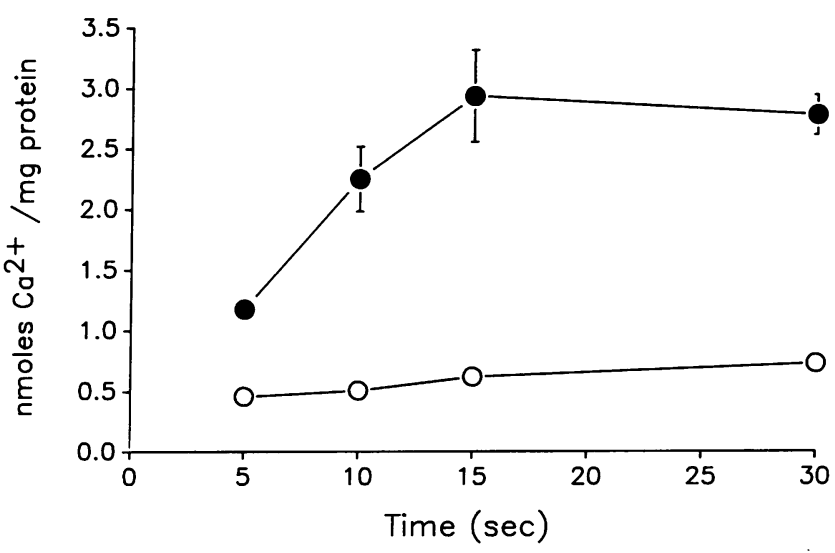

Figure 4. (A) Basal calcium uptake time course measured in nontreated control (open circles) and cholesterol-enriched (2:1 FC/PL; filled circles) VSMC. Calcium uptake was measured at time points ranging from $5 \mathrm{~s}$ to $8 \mathrm{~min}$ after the addition of $3 \mu \mathrm{Ci} / \mathrm{ml}$ of ${ }^{45} \mathrm{Ca}^{2+}$. (B) Expanded time scale for calcium uptake in control (open circles) and cholesterol-enriched ( filled circles) VSMC. All values represent mean \pm SEM of three experiments, each performed in triplicate.

Effect of calcium channel antagonists on calcium accumula tion in cholesterol-enriched VSMC. The possible role of voltage-sensitive calcium channels in the cholesterol-mediated increase in intracellular calcium content was evaluated using the voltage-dependent calcium channel antagonists verapamil, diltiazem, and nifedipine (Table II). In these studies, cholesterol enrichment increased intracellular calcium content by $84 \pm 9 \%$ compared to control VSMC not incubated with liposomes. Concurrent addition of verapamil $(10 \mu \mathrm{M})$, diltiazem $(1 \mu \mathrm{M})$, or nifedipine $(1 \mu \mathrm{M})$ during liposome exposure significantly attenuated the increase in intracellular calcium content in cholesterol-enriched VSMC compared to cholesterol-enriched VSMC. The calcium channel antagonists alone did not signifcantly affect the intracellular calcium content of control VSMC.

Addition of the calcium channel antagonists to the culture medium for $24 \mathrm{~h}$ had no effect on the magnitude of cellular FC enrichment induced by cholesterol-rich liposomes (liposomes 
Table II. Effects of Verapamil, Diltiazem, and Nifedipine on Intracellular Calcium Content of Control and Cholesterol-enriched VSMC

\begin{tabular}{lcr}
\hline \multicolumn{1}{c}{ Condition } & Percent change from control* & $n$ \\
\hline Verapamil (VP; $10 \mu \mathrm{M})$ & $-13 \pm 3$ & 4 \\
Diltiazem (DZ; $1 \mu \mathrm{M})$ & $-6 \pm 7$ & 4 \\
Nifedipine (NIF; $1 \mu \mathrm{M})$ & $-10 \pm 7$ & 3 \\
Cholesterol-enriched & $84 \pm 9^{\ddagger}$ & 12 \\
Cholesterol-enriched + VP & $42 \pm 19^{\ddagger}$ & 4 \\
Cholesterol-enriched + DZ & $48 \pm 10^{\ddagger 5}$ & 4 \\
Cholesterol-enriched + NIF & $64 \pm 9^{\ddagger}$ & 5
\end{tabular}

*Control intracellular calcium content was $7.2 \pm 0.6 \mathrm{nmol}$ calcium per milligram of cell protein $(n=12)$.

${ }^{\ddagger} P<0.02$ vs. control cells.

${ }^{\S} P<0.05$ vs. cholesterol-enriched cells.

alone, 20.6 $\pm 6.9 \mu \mathrm{g} \mathrm{FC} / \mathrm{mg}$ protein; liposomes plus calcium channel antagonists, $26.2 \pm 4.3 \mu \mathrm{g} \mathrm{FC} / \mathrm{mg}$ protein; $n=6$; $P=$ NS).

Effect of cholesterol enrichment on agonist-stimulated calcium uptake. Basal calcium uptake, assessed over a 1-min time period, averaged $0.510 \pm 0.020 \mathrm{nmol} / \mathrm{min}(n=4)$ in control VSMC. The addition of serotonin, vasopressin, endothelin, thrombin, or fetal calf serum each stimulated a marked increase in calcium uptake, ranging from a 28 to $94 \%$ increase over basal values in cholesterol-enriched VSMC (Table III). Basal calcium uptake was increased by $21 \pm 4 \%(P<0.001 ; n$ $=4$ ) in cholesterol-enriched VSMC as compared to control cells. In cholesterol-enriched VSMC, calcium uptake stimulated by endothelin, vasopressin, or thrombin was unchanged from that in control cells, but calcium uptake stimulated by serotonin and serum was significantly increased by $1.7-$ and 3.7-fold, respectively (Table III).

\section{Discussion}

These data show that enrichment of VSMC free cholesterol content causes an increase in the accumulation of intracellular calcium. This effect of cholesterol enrichment is associated with a marked increase in the rate of calcium uptake under basal conditions and in response to some, but not all, agonists. The increases in basal calcium accumulation and unidirectional calcium uptake are significantly inhibited by calcium channel antagonists.
The magnitude of the increase in calcium accumulation by cholesterol-enriched VSMC is linearly related to the extent of cellular free cholesterol enrichment. Incubation of VSMC with cholesterol-rich liposomes in the presence of an inhibitor of cholesterol esterification (16) resulted in the selective enrichment of cellular free cholesterol without changes in cellular esterified cholesterol or phospholipid, and was therefore associated with an increase in the molar ratio of free cholesterol to phospholipid, an index of membrane free cholesterol content (2). Since greater than $90 \%$ of cellular free cholesterol resides in the plasma membrane (24), it is very likely that the liposomemediated increase in cellular free cholesterol achieved in this study was associated with enrichment of the plasma membrane. Consistent with this thesis, Gleason and Tulenko (25) found in cultured smooth muscle cells from rabbit aorta that enrichment of free cholesterol with a combination of liposomes and LDL particles caused a selective enrichment of the plasma membrane. Other intracellular membranes (e.g., sarcoplasmic reticulum) may have also been enriched in free cholesterol, and potentially may have contributed to the alteration in cellular calcium handling.

A number of observations led us to consider the possibility that cholesterol enrichment would result in increased VSMC calcium accumulation. Locher et al. showed that cholesterol enrichment of erythrocyte membranes by incubation with cholesterol-rich liposomes resulted in an increase in calcium uptake, and that this effect was inhibited by verapamil (6). We previously found that perfusion of intact rabbit carotid artery with cholesterol-rich liposomes is associated with an increase in blood vessel calcium uptake, and that this effect is substantially inhibited by verapamil (8). Most recently, Gleason and Tulenko have presented evidence that cholesterol enrichment of cultured rabbit aortic smooth muscle cells using a combination of cholesterol-rich liposomes and LDL particles is associated with an increase in basal calcium influx (25).

The effect of cholesterol enrichment to increase unidirectional calcium uptake and intracellular calcium accumulation in this study is significantly inhibited by calcium channel antagonists. Calcium channel antagonists are known to affect the hydrolysis of esterified cholesterol (26) and the cellular handling of LDL (27). However, these effects cannot account for our findings, since in these experiments cholesterol esterification was blocked, and membrane cholesterol enrichment was accomplished without the use of LDL. The calcium channel antagonists also did not inhibit the ability of liposomes to enrich cellular free cholesterol. Therefore, we conclude that

Table III. Agonist-stimulated Calcium Uptake in Control VSMC and VSMC Incubated with Cholesterol-rich Liposomes (2:1 FC/PL)*

\begin{tabular}{|c|c|c|c|c|c|}
\hline Agonist & Control $^{\ddagger}$ & $2: 1^{\ddagger}$ & 2:1/Control & $P^{\$}$ & $n$ \\
\hline Serum $(10 \%)$ & $28 \pm 4$ & $74 \pm 9$ & $3.68 \pm 0.58$ & 0.001 & 6 \\
\hline Endothelin (10 nM) & $85 \pm 14$ & $82 \pm 7$ & $1.01 \pm 0.12$ & NS & 3 \\
\hline Vasopressin $(0.1 \mu \mathrm{M})$ & $69 \pm 3$ & $50 \pm 4$ & $0.73 \pm 0.03$ & NS & 2 \\
\hline Serotonin $(10 \mu \mathrm{M})$ & $25 \pm 5$ & $38 \pm 2$ & $1.70 \pm 0.23$ & 0.023 & 4 \\
\hline Thrombin $(5 \mathrm{U} / \mathrm{ml})$ & $94 \pm 14$ & $94 \pm 22$ & $0.98 \pm 0.13$ & NS & 3 \\
\hline
\end{tabular}

*Data are mean values of two to six experiments, as indicated, each performed in triplicate. ${ }^{\ddagger}$ Calcium uptake is presented as percent increase over basal calcium uptake, which averaged $0.510 \pm 0.020 \mathrm{nmol} / \mathrm{min}$ in control VSMC and $0.617 \pm 0.025 \mathrm{nmol} / \mathrm{min}$ in cholesterol-enriched $\operatorname{VSMC}\left(n=4\right.$ each). ${ }^{\S}$ Control vs. $2: 1$. 
calcium channel antagonists inhibit the effect of cholesterolrich liposomes to increase VSMC calcium accumulation at a step subsequent to membrane free cholesterol enrichment.

The observation that calcium channel antagonists from three distinct pharmacologic classes shared the ability to inhibit calcium accumulation in cholesterol enriched cells strongly suggests that calcium channels are involved, either primarily or secondarily, in mediating this effect of cholesterol enrichment on calcium accumulation. Although the calcium channel antagonists used in these experiments are relatively selective for Ltype channels, they may also inhibit receptor-operated calcium channels, and may have actions other than to inhibit transplasmalemmal calcium influx (28). Finally, it should be noted that the calcium channel antagonists did not fully block the effect of cholesterol enrichment, suggesting that a second mechanism of calcium accumulation, not sensitive to calcium channel antagonists, may also be involved. Clarification of the specific site(s) at which cholesterol acts to increase calcium influx and accumulation will require further study. Although it is known that the cholesterol content of a lipid bilayer may influence the physical state of the bilayer (2), the permeability to ions (5), and the function of integral membrane proteins $(3,4)$, the role of these or other actions of membrane cholesterol in the regulation of VSMC calcium influx remains to be determined.

Since VSMC enrichment caused an increase in basal calcium uptake, it was of interest to know whether agonist-stimulated calcium uptake would also be potentiated by cholesterol enrichment. The calcium uptake stimulated by serotonin and serum was increased by cholesterol enrichment, whereas that stimulated by endothelin, vasopressin, and thrombin was not affected. Thus, the effect of cholesterol enrichment on agoniststimulated calcium uptake is agonist selective. This selectivity is consistent with the possibility that cholesterol enrichment affects agonist-stimulated calcium influx at a site before the calcium influx channel (e.g., the agonist receptor or a G-protein). Of note, Cohen et al. reached an analogous conclusion with regard to the agonist-selective loss of endothelium-dependent vasodilation caused by hypercholesterolemia (29). It is possible that the effects of cholesterol enrichment on basal and agonist-stimulated calcium influx are due to the actions of cholesterol enrichment on two or more effector sites (e.g., the calcium influx channel and the agonist receptor). Alternatively, cholesterol enrichment may increase basal and agonist-stimulated calcium influx by acting at a single site such as a G-protein, which both regulates basal calcium channel function and couples selectively to certain agonist receptors (i.e., serotonin). The effect of cholesterol enrichment on serum-stimulated calcium uptake is particularly striking, and may be pertinent to the observation that cholesterol enrichment of rabbit aortic VSMC potentiates serum-stimulated DNA synthesis (30).

The findings of this study may be relevant to conditions characterized by excess cholesterol accumulation in the vasculature. A characteristic feature of atherosclerosis is the deposition of both cholesterol and calcium within the arterial wall. Some of this excess cholesterol accumulates in the extracellular space or as esterified cholesterol in both vascular smooth muscle cells (31) and nonvascular cells (e.g., macrophages). However, Haley et al. have shown in VSMC from cholesterol-fed rabbit aorta that free cholesterol is enriched approximately twofold, even in cells not exhibiting intracellular accumulation of esterified cholesterol (31). Likewise, although much of the calcium in atherosclerotic lesions is extracellular, possibly reflecting debris from necrotic VSMC, Strickberger et al. have provided indirect evidence to support the hypothesis that the uptake and intracellular accumulation of calcium by atherosclerotic rabbit aortic smooth muscle is markedly increased (7, 32). Our data provide direct mechanistic support for this hypothesis by showing that calcium uptake and intracellular calcium content of the VSMC are increased by the enrichment of membrane free cholesterol. These data further suggest that an increased responsiveness of the VSMC to certain vasoactive substances and growth factors could contribute to the abnormal calcium homeostasis observed in hypercholesterolemia.

The role of VSMC calcium accumulation in the pathophysiology of atherosclerosis, if any, is not known (32). However, there is evidence that calcium channel antagonists, including verapamil, nifedipine, and diltiazem, inhibit atherosclerotic plaque formation in animals (32-36), and inhibit serum-stimulated proliferation and DNA synthesis in cultured VSMC (37). A recent clinical trial concluded that nifedipine signifcantly suppressed the formation of new atherosclerotic lesions in patients (38). Our findings provide one mechanism by which calcium channel antagonists might affect calcium accumulation in the VSMC. Of note, the cholesterol-induced accumulation of intracellular calcium was reversed concomitant with removal of the excess VSMC free cholesterol with cholesterolpoor liposomes. We conclude that a cholesterol-induced alteration in the handling of calcium by VSMC may represent an early, potentially reversible, form of injury, the functional consequence(s) of which might play a role in such processes as VSMC proliferation, migration, cell death, and enhanced sensitivity to vasoconstrictor substances $(10,11,32,35,39,40)$.

\section{Acknowledgments}

The authors wish to thank Dr. Thomas J. Kulik for generously providing VSMC, Dr. Nicholas Izzo for his critical comments in the course of this study, and Dr. James Paternitti for providing Sandoz Compound 58-035. We also thank Dr. Carlo Brugnara for his help and guidance in the use of the atomic absorption spectrometer and Erin Smith for her skillful technical assistance.

Supported in part by National Institutes of Health grants RO1HL42539-1 and R01-HL30496-5. R. A. Bialecki was supported in part by a postdoctoral research fellowship of the American Heart Association, Massachusetts Affiliate. W. S. Colucci is an AHA-Sandoz Established Investigator of the American Heart Association.

\section{References}

1. Cooper, R. A., M. H. Leslie, S. Fischkoff, M. Shinitzky, and S. J. Shattil. 1978. Factors influencing the lipid composition and fluidity of red cell membranes in vitro: production of red cells possessing more than two cholesterols per phospholipid. Biochemistry. 17:327-331.

2. Quinn, J. 1980. The fluidity of cell membranes and its regulation. Prog. Biophys. Mol. Biol. 38:1-104.

3. Ortega, A., and J. Mas-Oliva. 1986. Direct regulatory effect of cholesterol on the calmodulin stimulated calcium pump of cardiac sarcolemma. Biochem. Biophys. Res. Commun. 139:868-874.

4. Kimelberg, H. K., and D. Papahadjopoulos. 1974. Effect of phospholipid acyl chain fluidity, phase transitions and cholesterol on $\mathrm{Na}^{+} / \mathrm{K}^{+}$-stimulated adenosine triphosphatase. J. Biol. Chem. 249:1071-1077.

5. Pope, C. G., B. W. Urban, and D. A. Haydon. 1982. The influence of $\mathrm{n}$-alkanols and cholesterol on the duration and conductance of gramicidin single channels in monoolein bilayers. Biochim. Biophys. Acta. 688:279-283.

6. Locher, R., L. Neyes, M. Stimpel, B. Kuffer, and W. Vetter. 1984. The cholesterol content of the human erythrocyte influences calcium influx through the channel. Biochem. Biophys. Res. Commun. 124:822-829. 
7. Strickberger, S. A., L. N. Russek, and R. D. Phair. 1988. Evidence for increased aortic plasma membrane calcium transport caused by experimental athrosclerosis in rabbits. Circ. Res. 62:75-80.

8. Bialecki, R. A., and T. N. Tulenko. 1989. Excess membrane cholesterol alters calcium channels in arterial smooth muscle. Am. J. Physiol. 257:C306C314.

9. Broderick, R., R. Bialecki, and T. N. Tulenko. 1989. Cholesterol-induced changes in arterial sensitivity to adrenergic stimulation. Am. J. Physiol. 257:H170-H178.

10. Heistad, D. D., M. L. Armstrong, M. L. Marcus, D. J. Piegers, and A. L Mark. 1984. Augmented responses to vasoconstrictor stimuli in hypercholesterolemic and atherosclerotic monkeys. Circ. Res. 54:711-718.

11. Merkel, L. A., L. M. Rivera, G. E. Bilder, and M. H. Perrone. 1990. Differential alteration of vascular reactivity in rabbit aorta with modest elevation of serum cholesterol. Circ. Res. 67:550-555.

12. Galle, J., E. Bassenge, and R. Busse. 1990. Oxidized low density lipoproteins potentiate vasoconstrictions to various agonists by direct interaction with vascular smooth muscle. Circ. Res. 66:1287-1293.

13. Lopez, J. A. G., M. L. Armstrong, D. J. Piegors, and D. D. Heistad. 1990. Vascular responses to endothelin-1 in atherosclerotic primates. Arteriosclerosis. 10:1113-1118.

14. Rothman, A., T. J. Kulik, M. B. Taubman, B. C. Berk, and B. Nadal-Ginard. 1988. Rat pulmonary smooth muscle cells maintain differentiated properties in culture. Circulation. 78:II-232. (Abstr.)

15. Rothman, A., M. B. Taubman, T. J. Kulik, and B. Nadal-Ginard. 1988. Differential expression of contractile protein mRNA in rat pulmonary artery smooth muscle cells. Circulation. 78:II-66. (Abstr.)

16. Ross, A. C., K. J. Go, J. G. Heider, and G. H. Rothblat. 1984. Selective inhibition of acyl coenzyme A: cholesterol acyltransferase by compound 58-035. J. Biol. Chem. 259:815-819.

17. Sperti, G., and W. S. Colucci. 1987. Phorbol ester-stimulated bidirectional transmembrane calcium flux in $\mathrm{A}_{7} \mathrm{r} 5$ vascular smooth muscle cells. Mol. Pharmacol. $32: 37-42$.

18. Deth, R. C. 1978. Effect of lanthanum and reduced temperature on ${ }^{45} \mathrm{Ca}^{2+}$ efflux from rabbit aorta. Am. J. Physiol. 234:C139-C145.

19. Van Breemen, C., B. R. Farinas, P. Gerba, and E. D. McNaughton. 1972. Excitation-contraction coupling in rabbit aorta studied by the lanthanum method for measuring cellular calcium influx. Circ. Res. 30:33-54.

20. Brown, R. D., K. D. Berger, and P. E. Taylor. 1984. $\alpha_{1}$-adrenergic receptor activation mobilizes cellular calcium in a muscle cell line. J. Biol. Chem. 259:7554-7562.

21. Gamble, W., M. Vaughan, H. S. Kruth, and J. Avigan. 1978. Procedure for the determination of free and total cholesterol in micro- or nanogram amounts suitable for studies with cultured cells. J. Lipid Res. 19:1068-1070.

22. Sokaloff, L., and G. H. Rothblat. 1974. Sterol to phospholipid molar ratios of $L$ cells with qualitative and quantitative variations of cellular sterol. Proc. Soc. Exp. Biol. Med. 146:1166-1172.

23. Lowry, O. H., N. J. Rosebrough, A. L. Farr, and R. J. Randall. 1951. Protein measurement with the Folin phenol reagent. J. Biol. Chem. 193:265-275.

24. Lange, Y., M. H. Swaisgood, B. V. Ramos, and T. L. Steck. 1989. Plasma membranes contain half the phospholipid and $90 \%$ of the cholesterol and sphingomyelin in cultured human fibroblasts. J. Biol. Chem. 264:3786-3793.

25. Gleason, M. M., and T. N. Tulenko. 1989. The relationship between membrane cholesterol content and transmembrane calcium movements in cultured arterial smooth muscle cells. FASEB (Fed. Am. Soc. Exp. Biol.) J. 3:A256. (Abstr.)

26. Stein, O., G. Halperin, and Y. Stein. 1987. Long-term effect of verapamil on aortic smooth muscle cells cultured in the presence of hypercholesterolemic serum. Atherosclerosis. 7:585-592.

27. Etingin, O. R., and D. P. Hajjar. 1985. Nifedipine increases cholesterol ester hydrolytic activity in lipid-laden rabbit arterial smooth muscle cells. J. Clin. Invest. 75:1554-1558.

28. Triggle, D. J., and R. A. Janis. 1987. Calcium channel ligands: structurefunction relationships. In Structure and Physiology of the Slow Inward Calcium Channel. D. J. Triggle, editor. Alan R. Liss, Inc., NY. 29-50.

29. Cohen, R. A., K. M. Zitnay, C. C. Haudenschild, and L. D. Cunningham. 1988. Loss of selective endothelial cell vasoactive functions caused by hypercholesterolemia in pig coronary arteries. Circ. Res. 63:903-910.

30. Tulenko, T. N. 1991. Atherogenic activity of excess membrane cholesterol in arterial smooth muscle and endothelial cells. J. Am. Coll. Cardiol. 17:24A. (Abstr.)

31. Haley, J. N., H. Shio, and S. Fowler. 1977. Characterization of lipid-laden aortic cells from cholesterol-fed rabbits. I. Resolution of aortic cell populations by metrizamide density gradient centrifugation. Lab. Invest. 37:287-296.

32. Phair, R. D. 1988. Cellular calcium and atherosclerosis: a brief review. Cell Calcium. 9:275-284.

33. Chan, C. T., H. Wells, and D. M. Kramsch. 1978. Suppression of calcific fiberous-fatty plaque formation in rabbits by agents not effecting elevated serum cholesterol levels. Circ. Res. 43:115-125.

34. Kramsch, D. M., A. J. Aspen, and C. S. Apstein. 1980. Suppression of experimental atherosclerosis by the $\mathrm{Ca}^{2+}$-antagonist lanthanum. J. Clin. Invest. 65:967-981.

35. Fleckenstein, A., M. Frey, J. Zorn, and G. Fleckenstein-Grun. 1987. The role of calcium in the pathogenesis of experimental arteriosclerosis. Trends Pharmacol. Sci. 8:496-501.

36. Henry, P. D., and K. I. Bentley. 1981. Suppression of atherogenesis in cholesterol-fed rabbit treated with nifedipine. J. Clin. Invest. 68:1366-1369.

37. Sperti, G., and W. S. Colucci. 1991. Calcium influx modulates DNA synthesis and proliferation in $\mathrm{A}_{7} \mathrm{r}_{5}$ vascular smooth muscle cells. Eur. J. Pharmacol. In press.

38. Lichtlen, P. R., P. G. Hugenholtz, W. Rafflenbeul, H. Hecker, S. Jost, and J. W. Deckers. 1990. Retardation of angiographic progression of coronary artery disease by nifedipine: results of the International Nifedipine Trial on Atherosclerotic Therapy (INTACT). Lancet. 335:1109-1113.

39. Yokoyama, M., and P. D. Henry. 1979. Sensitization of isolated canine coronary arteries to calcium ions after exposure to cholesterol. Circ. Res. 45:479486.

40. Shimokawa, H., H. Tomoike, S. Nakayama, H. Yamamoto, H. Araki, and M. Nakamura. 1983. Coronary artery spasm induced in atherosclerotic swine. Nature (Lond.) 221:560-561. 